\title{
CHANGING NEAR-STREAM LAND USE AND RIVER CHANNEL MORPHOLOGY IN THE VENEZUELAN ANDES ${ }^{1}$
}

\author{
Diana L. Karwan, J. David Allan, and Kathleen M. Bergen ${ }^{2}$
}

\begin{abstract}
The shape of a river channel is linked to surrounding land use through interacting hydrologic and geologic processes. This study analyzes the relationship between the change in nearstream land use and the shape of the adjacent river channel over time. Three watersheds in the foothills of the Venezuelan Andes that have experienced differing degrees of development were studied to determine river channel width, sinuosity, and position relative to surrounding land use. Change in land use over time was obtained from multiple-date aerial photographs (1946 and 1980) referenced to 1996 Landsat Thematic Mapper (TM) satellite imagery, and verified by field inspection. Measurements of land-use type and amount and river channel morphology from the two dates were made using geographic information system (GIS) methods. The three watersheds differed in the extent of deforestation, the location of remaining forested land, and how much land-use change had already occurred by 1946. Change in river channel morphology was greatest at the most deforested sites. Valley shape and channel constraint also had a discernible effect on change in channel morphology. This study introduces a method for analyzing change in coupled terrestrial-aquatic systems based on multiple-date, remotely sensed data and GIS analysis of spatial properties. The results document human impacts on river channels through a comparison of multiple watersheds over a 35-year time interval.

(KEY TERMS: aerial photography; geographic information systems; remote sensing; land-use change; rivers; channel morphology; riparian, watershed.)
\end{abstract}

\section{INTRODUCTION}

River channels tend towards an approximate steady state in which channel dimensions, sinuosity, and other aspects of channel morphology adjust dynamically to the hydrologic and sediment load of the river, subject to constraints such as degree of valley confinement (Schumm, 1977). Human-induced changes to the landscape or the river channel, by altering hydrology or sediment supply, or by influencing the resistance of the channel to erosion, can therefore induce changes in the river channel. Deforestation can significantly alter river channels by changing runoff and increasing sediment delivery from the upper basin. Total runoff and magnitude of peakflow increase when forest is replaced by cropland, due largely to reduced evapotranspiration (Bruijnzeel and Bremmer, 1989). Gentry and Lopez-Parodi (1980) reported an increase in the annual height of the Amazon's flood crest over 1962 to 1978, despite no significant change in precipitation, which they attributed to forest loss within the Amazon basin. Changes to hydrologic and sediment budgets in turn may lessen channel stability (Schumm, 1977). Comparing 1944 to 1976 aerial photography of alluvial rivers in northern Argentina, Sayago and Guido (1991) found increases in width and decreases in sinuosity, producing a change from a meandering to a braided channel and a larger floodplain. They attributed these changes to altered sediment budgets in the upper watershed. In a study of post-settlement (1938 to 1989) land-use change in an Ozarks (Missouri) stream that was recovering following a decline in historic timber harvest and open-range grazing, Jacobson and Pugh (1997) concluded that hydrologic and sediment budgets were insufficiently altered by land-use practices to cause channel instability. They argued that historic timber harvest and open-range grazing had destabilized the channel, and that

1Paper No. 01028 of the Journal of the American Water Resources Association. Discussions are open until August 1, 2002.

2Respectively, Recent Graduate, School of Natural Resources and Environment, University of Michigan-Ann Arbor, 30789 Minton, Livonia, Michigan 48150; Professor, School of Natural Resources and Environment, University of Michigan, 430 East University, Ann Arbor, Michigan 48109-1115; and Assistant Research Scientist, School of Natural Resources and Environment, University of Michigan, 430 East University, Ann Arbor, Michigan 48109-1115 (E-Mail:Karwan: dkarwan@umich.edu). 
regrowth of woody riparian vegetation was the primary cause of increased channel stability over the time period of observation.

Anthropogenic development in developing regions typically increases the extent of agricultural and urban land at the expense of the amount of remaining forest cover. Such changes have been found to result in significant impacts on physical characteristics and biotic integrity of rivers (Roth et al., 1996; Castillo et al., 2000). Degradation of river habitat resulting from changes in surrounding land use is widely considered to be the connecting link between land-use change and biotic responses (Richards et al., 1996; Allan et al., 1997).

This study investigates the relationship between land-use change and channel morphology in three watersheds in the Venezuelan Andes that have different geomorphological constraints as well as differing rates of development. We use a method for analyzing change in coupled terrestrial-aquatic systems that is based on multiple-date, remotely sensed data and GIS analysis of spatial characteristics.

Use of aerial photography and other remotely sensed data to classify land use has become a standard application over the last several decades (Anderson et al., 1976; Cihlar et al., 2000) and theory and techniques are widely described in the literature. There also is a growing literature using remote sensing to detect land-cover and land-use change (e.g., Franklin et al., 2000). Use of remotely sensed data specifically to assess river channel morphology is less widespread. Several studies have used aerial photography to analyze river channel morphology, including sinuosity (Schumm, 1963), channel area (Hallberg et al., 1979), changes in channel width (Schumm and Lichty, 1963; Beschta, 1983; Odgaard, 1984; Kondolf and Curry, 1986), channel shape and depth (Gilvear et al., 1995), cross-sectional shape (Jureck, 2000), and width, meander wavelength, sinuosity, and expansion of alluvial plain (Sayago and Guido, 1991).

In the present study, we combine these two applications of remotely sensed data and use multiple-date aerial photography (1946 and 1980) in conjunction with GIS-based spatial analysis methods to analyze both the river and the surrounding land use to determine the effects of change in land use on river channel morphology.

\section{STUDY AREA}

The piedmont region of Venezuela lies at an elevation of 200 to $400 \mathrm{~m}$, where rivers originating in the Andes approach the Llanos, a tropical savanna of low relief. The three study watersheds (Figure 1) occur along a development and disturbance gradient, from most developed and disturbed in the Northeast, to least disturbed in the Southwest (Allan et al., 2001). The watersheds of Rios Las Marias, La Yuca, and Bumbum were chosen for analysis based on expected contrasts in the extent and timing of prior land-use change. All watersheds are in close geographic proximity and similar topographic position with their channels running essentially parallel as they enter the Llanos in the interior of Venezuela as part of the Apure-Orinoco drainage.

Beginning in the Northeast (Figure 1), Las Marias is the most disturbed of the three watersheds. The river originates at $1400 \mathrm{~m}$ above sea level and meanders through a wide, level valley below about $400 \mathrm{~m}$. The majority of the land area in this watershed lies below $800 \mathrm{~m}$, and the entire watershed is settled. The number of buildings (derived from 1960s topographic maps, thus a measure of human habitation at the mid-point of our multiple-date comparison) indicates greater settlement of Las Marias compared to the other two watersheds (Table 1). Currently, the land use includes scattered gallery forest remnants, some secondary forest, and cattle ranches and agriculture on both subsistence and larger scales. Main agricultural crops include maize and coffee (Allan et al., 2001, personal observation).

The La Yuca watershed, located near the center of our NE-SW line of disturbance, has topography and current land use similar to that of Las Marias. However, widespread population appeared later in La Yuca than Las Marias. As of 1960, the watershed had isolated clusters of habitations. Since that time, these isolated clusters have grown and become connected by a network of roads that extend to cover much of the watershed.

The Bumbum has the least overall watershed development (Allan et al., 2001). This river originates at $3600 \mathrm{~m}$ above sea level and occupies a steep-sided valley. There are few roads in this watershed, which in 1960 and still today is the least populated of the three studied (Table 1). Houses and small farms follow the river and its parallel road upstream for approximately $10 \mathrm{~km}$. Above $700 \mathrm{~m}$ elevation, this watershed remains inaccessible primary forest, lacking even foot-trails (personal observation).

Riverbed substrate particles tended to be smallest in Rio Las Marias and largest in Rio Bumbum. Las Marias also had the flattest lateral valley, and Rio Bumbum the steepest (Table 1). Thus, natural differences in bed material and valley constraint also differed among the three watersheds. 


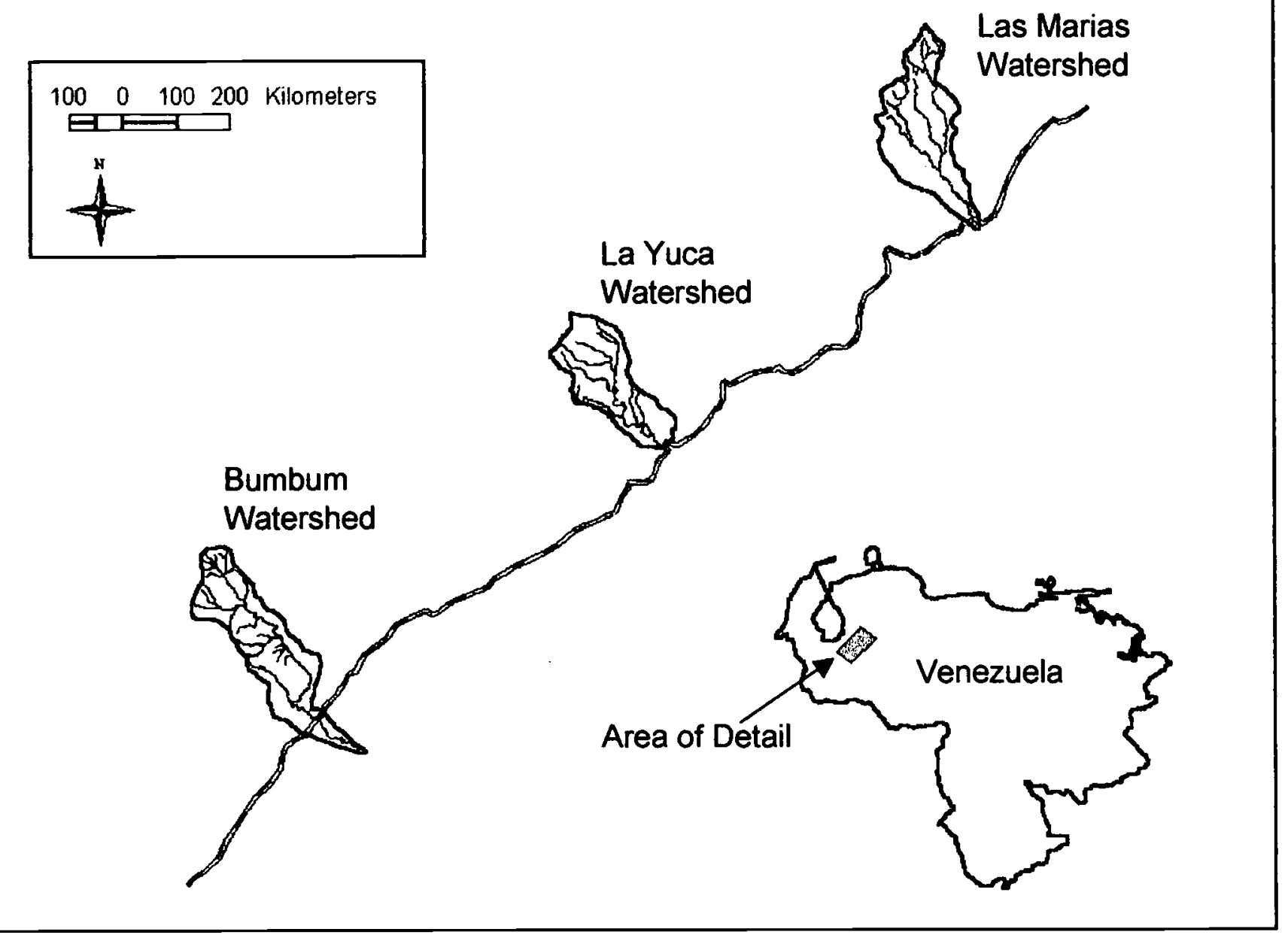

Figure 1. Location of the Three Study Watersheds in the Venezuelan Andes. Each watershed is truncated for the purposes of this study $1 \mathrm{~km}$ below the Llanos alto Highway, but each river traverses the Ilanos to join the Rio Apure, a major tributary of the Orinoco River.

\section{METHODS}

We selected study sites in each watershed based on availability of multiple-date black and white panchromatic aerial photography from 1946 and 1978 to 1981 (hereafter referred to as 1980 ), their proximity to the field study sites of Allan et al. (2001), and availability of cloud-free Landsat Thematic Mapper (TM) imagery. The Landsat TM data and the field study sites were necessary for rectification of the aerial photography and basic knowledge of the area, respectively. Field observations in July 1999 provided in-situ information on the current conditions of the study sites and their greater watersheds. Each study site was located in the lower portion of the watershed, at approximately $300 \mathrm{~m}$ in elevation (Table 1), and comprised $14 \mathrm{~km}$ of river channel and the surrounding approximately $40 \mathrm{~km}^{2}$ of land.
Comparison of 1946 and 1980 aerial photography allowed for examination of the change in landscape and river conditions over a 35-year period. First, geographic data were georectified and placed in a common projection so they could be precisely overlaid and analyzed in a GIS. This was completed using ERDAS Imagine 8.3.1 software (ERDAS Inc, Atlanta, Georgia), and a previously georectified cloud-free 1996 Landsat TM image. The Landsat TM image was used for reference and georectification purposes but not for land-use comparisons because it offered $30 \mathrm{~m}$ resolution at best, while the scanned and rectified aerial photographs had $3 \mathrm{~m}$ resolution. The 1980 photography was scanned and georectified to the reference 1996 Landsat TM image. The 1946 photography was scanned and georectified to the 1980 photography. The area of overlapping photo coverage from the two time periods determined the final study area, which 
TABLE 1. Some Characteristics of the Three Study Watersheds in the Venezuelan Andes. Measures of total watershed area and stream length are derived from a lower boundary set $1 \mathrm{~km}$ below the Llanos Alto Highway.

\begin{tabular}{|c|c|c|c|}
\hline & Las Marias & La Yuca & Bumbum \\
\hline Area of Watershed $\left(\mathrm{km}^{2}\right)$ & 331 & 262 & 358 \\
\hline Elevation at Origin (m) & 1400 & 1400 & 3600 \\
\hline Elevation of Study Section (m) & 260 & 300 & 320 \\
\hline Total River Distance & 138 & 123 & 167 \\
\hline Lateral Valley Slope ${ }^{a}$ & 0.0 & 0.05 & 0.18 \\
\hline Dominant Substrate Size $(\mathrm{cm})^{b}$ & $5-15$ & $5-25$ & $5-40$ \\
\hline Largest Substrate Size $(\mathrm{cm})^{b}$ & $30-40$ & $60-90$ & $90 \cdot 100$ \\
\hline Drivable Road Access & Extensive & Primarily in lower areas & Limited in lower areas \\
\hline Number of buildings, $1960^{c}$ & 324 & 89 & 8 \\
\hline Current population settlement & Throughout watershed & Primarily in lower areas & Very limited in lower areas only \\
\hline
\end{tabular}

included approximately $14 \mathrm{~km}$ of linear river distance and all surrounding land covered by both sets of aerial photographs. Once aligned and clipped to the study area, the photography was examined for changes in land-use and river channel conditions.

Land-use change was measured by manual interpretation of the scanned and georectified photography. The U.S. Geological Survey (Anderson et al., 1976) land-cover/use classification scheme was used at Level I for classifying land-use polygons as: (1) urban, (2) agriculture, (3) rangeland, (4) forest, (5) water, or (6) barren land. Land-use polygons with a minimum mapping unit of 0.05 hectares were identified and digitized as separate polygons and labeled with Level I land use. Because of the high spatial resolution of the aerial photography, the rivers were also digitized as polygons. Digitizing was done on-screen in ERDAS Imagine, after photos had been georectified. The digitized polygon data was converted into ArcInfo coverages. All remaining spatial analysis was performed in ArcInfo 7.2 and ArcView 3.1a (ESRI Inc., Redlands, California).

Sites were visited in July 1999 for ground validation of land-use classification and to further examine the extent of human development. Upon field visits in addition to the examination of historical aerial photography, it was determined that our initial landcover/use categories of rangeland and pasture consisted entirely of grazing pasture. Consequentially, in this study, rangeland and pasture were combined into the one land-use class - rangeland.

Stream width was measured in ArcView using data digitized from the photography. A line was first digitized down the center of the stream polygon created in the land-use delineation described above. Systematic sampling with a random start was then applied to determine the width measurement locations. Nodes were systematically inserted every fifty meters using the Routehatch extension of ArcView 3.1B. At each node along the river, an orthogonal river transect was digitized and its length computed. A total of 280 transect measurements were averaged to obtain average river width for each stream segment.

Sinuosity was determined by dividing the distance along the centerline of each river by the straight-line distance between the end points of the study segment (Gordon et al., 1992). Due to river curvature and branching it was necessary in some cases to compute a weighted average of several subsegments to compute sinuosity.

\section{RESULTS}

Interpretation of the aerial photography revealed substantial differences between the three study regions at both time periods (Figure 2). As of 1946, Las Marias showed considerable agricultural land and some road access in what presumably was once a forested area, whereas the Bumbum study section was entirely forested and roadless, and La Yuca was mostly forested. The number of buildings within each watershed, at the date of the circa 1960s large-scale topographic maps, also differs greatly (Table 1) in 

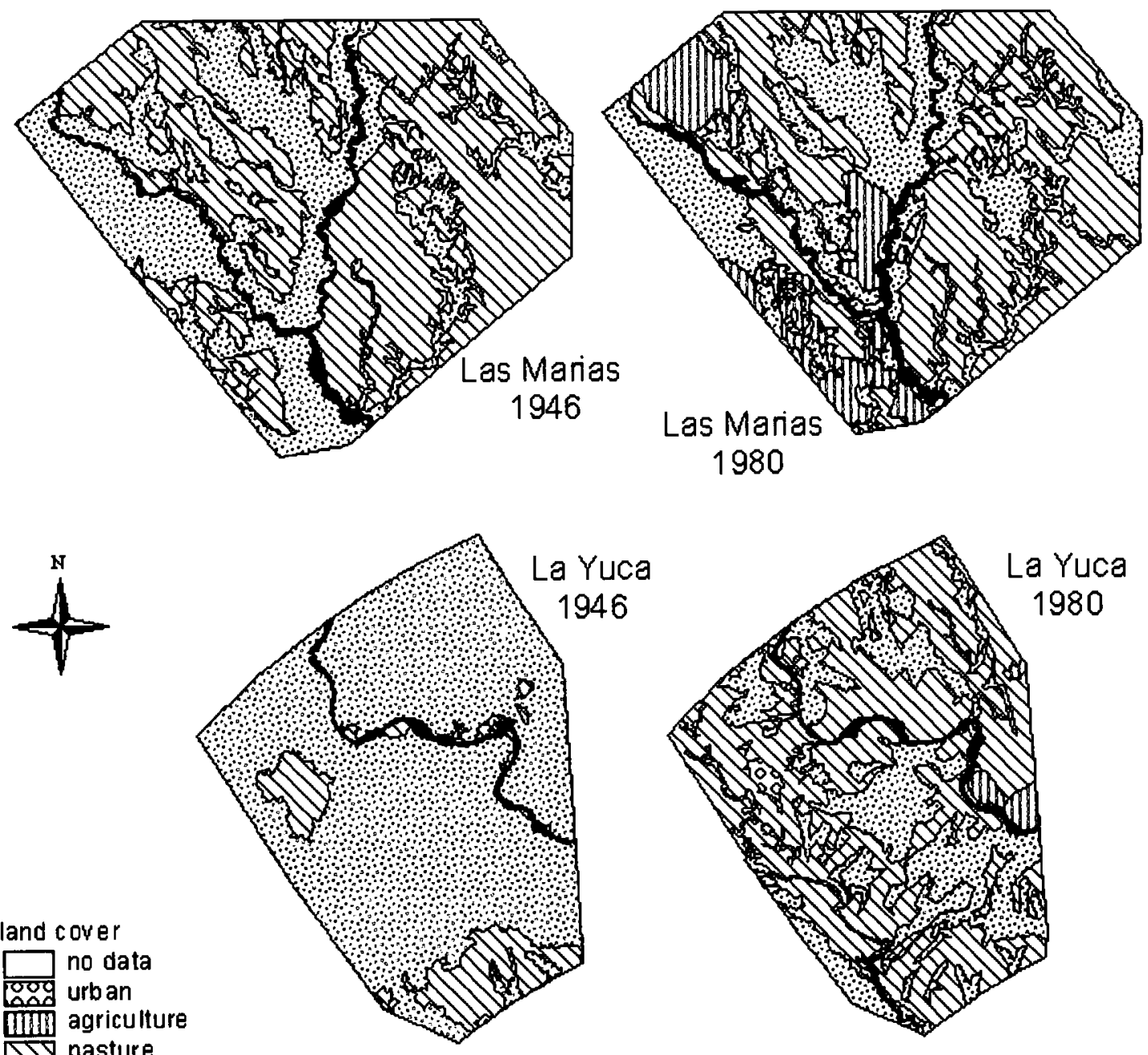

land cover

$\square$ no data

Oुण्व urb an

DIIID agriculture

DI pasture

Forest

water
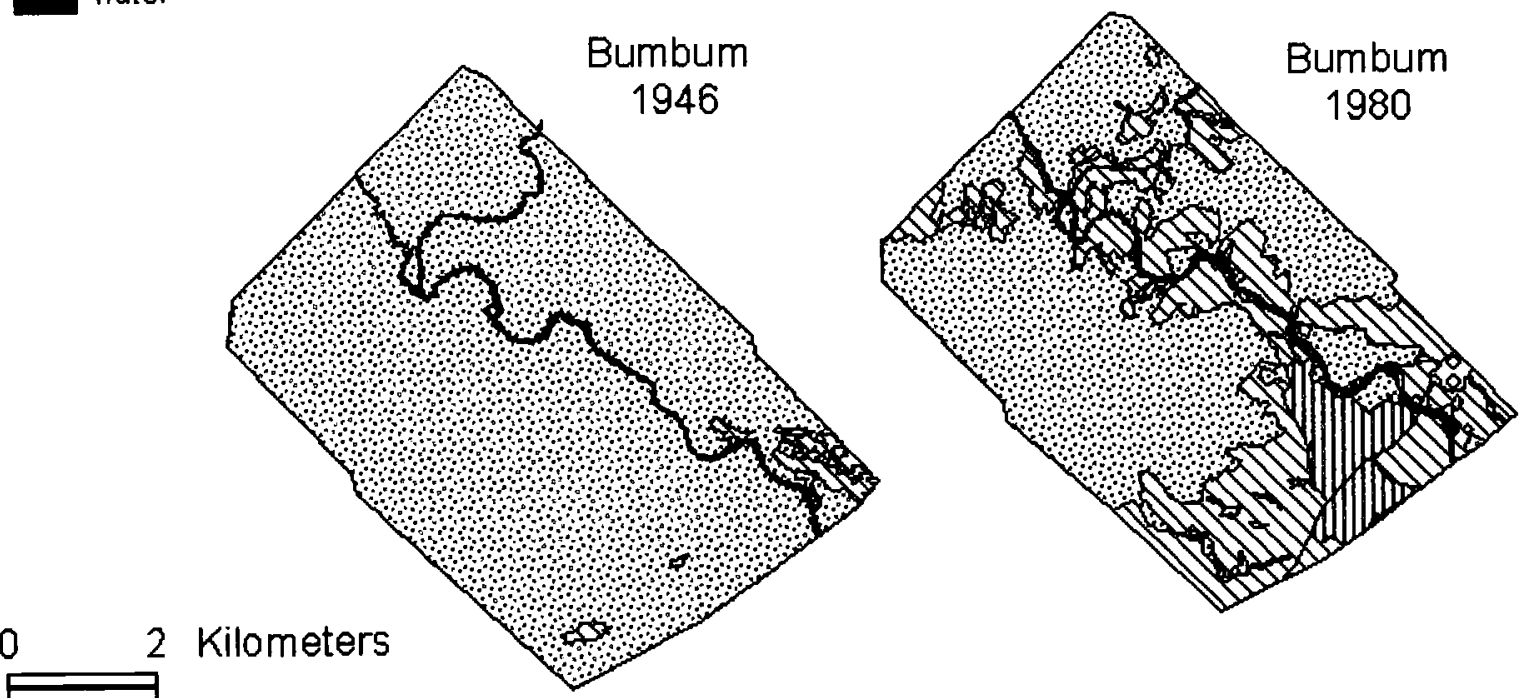

Figure 2. Land Use/Cover of the Three Study Areas, Derived From 1946 (left) and 1980 (right) Aerial Photography. 
accord with the Northeast to Southwest disturbance trend observable in comparing these watersheds (Allan et al., 2001).

Analysis of land-use change between 1946 and 1980 from aerial photography documented for the study sites is in accordance with the extensive landuse change that took place in the latter half of the twentieth century in Venezuela. Las Marias had no visible row-crop agriculture in 1946, although pasture covered over half of the surrounding land area. By 1980 , cultivated agriculture (primarily maize, based on recent field surveys) was 12 percent of the landuse, and both pasture and forest had declined (Table 2). The La Yuca study area experienced the greatest change in land-use between 1946 and 1980. Forested land comprised nearly 90 percent of the area surrounding the stream in 1946 ; by 1980 it had decreased to less than 40 percent, largely due to conversion to pasture, which increased greatly to nearly 60 percent. Cultivated cropland ( 2 percent) and urban land ( 1 percent) both appear in 1980 photography. The Bumbum study area experienced a dramatic change from its virtually undisturbed state (97 percent forest) of 1946. Pasture and grassland increased from 2 percent in 1946 to 30 percent in 1980. Additionally, cultivated cropland and urban land first appeared in the 1980 photography, comprising 8 percent of the study area. During this time the town of Bumbum was established, forming 1 percent of the study area.

This deforestation and landscape development was associated with changing river channel morphology (Table 2). The average width of the Las Marias river channel increased by 50 percent, while channel position also underwent a marked change, as one channel section was abandoned to become a side channel, and a new main channel formed. Only a very small decrease in sinuosity was detected. Average channel width of Rio La Yuca remained unchanged; however, channel position and occurrence of islands within the river channel changed considerably (Figure 3 ). Because channel position and land use changed so significantly, ground control points became difficult to locate, thus sinuosity was not measured. In the Rio Bumbum, the 1980 average channel width had increased to 126 percent of its 1946 width. Neither channel position nor sinuosity changed detectably, however (Table 2).

\section{DISCUSSION}

In this study we used multiple-date, remotely sensed data combined with spatial analytical techniques to quantify the relationships between land use and river morphology in three Venezuelan watersheds. While a range of aerial and satellite data have the spatial and spectral properties needed for characterizing land use or land-use change, two constraints when using remotely sensed data to analyze problems involving change in meso-scale river morphology are spatial resolution and availability of retrospective data. This made large-scale aerial photography an effective choice, due to its high spatial resolution, historical availability, and its relatively low cost. Other studies have also confirmed the utility of aerial photography for accurate characterization of river morphology (Gilvear et al., 1995). Spatial analysis software and techniques were used with the digitized remotely sensed data to efficiently derive area, distance, shape, proximity, and other spatial measures and relationships and their change over time in the coupled terrestrial-aquatic systems.

The three study watersheds underwent substantial change in land-use over the time interval of 1946 to 1980. The study area of the Las Marias watershed had less than half of its area in forest in 1946 ,

TABLE 2. Changes in Land Cover and Channel Shape Between 1946 and 1980 in Three Study Watersheds.

\begin{tabular}{|c|c|c|c|c|c|c|}
\hline & \multicolumn{2}{|c|}{ Las Marias } & \multicolumn{2}{|c|}{ La Yuca } & \multicolumn{2}{|c|}{ Bumbum } \\
\hline & 1946 & 1980 & 1946 & 1980 & 1946 & 1980 \\
\hline \multicolumn{7}{|l|}{ Land Cover } \\
\hline Percent Forest & 42.2 & 36.9 & 89.4 & 38.1 & 96.9 & 60.8 \\
\hline Percent Pasture & 55.4 & 47.9 & 10.6 & 58.5 & 1.9 & 30.1 \\
\hline Percent Agriculture & 0 & 12.2 & 0 & 1.9 & 0 & 6.6 \\
\hline \multicolumn{7}{|l|}{ Channel } \\
\hline Width (m) & 74.3 & 110.6 & 69.4 & 66.4 & 33.7 & 42.5 \\
\hline Sinuosity & 1.18 & 1.16 & - & - & 1.24 & 1.23 \\
\hline Position Shifts & \multicolumn{2}{|c|}{ yes } & \multicolumn{2}{|c|}{ yes } & \multicolumn{2}{|c|}{ no } \\
\hline
\end{tabular}




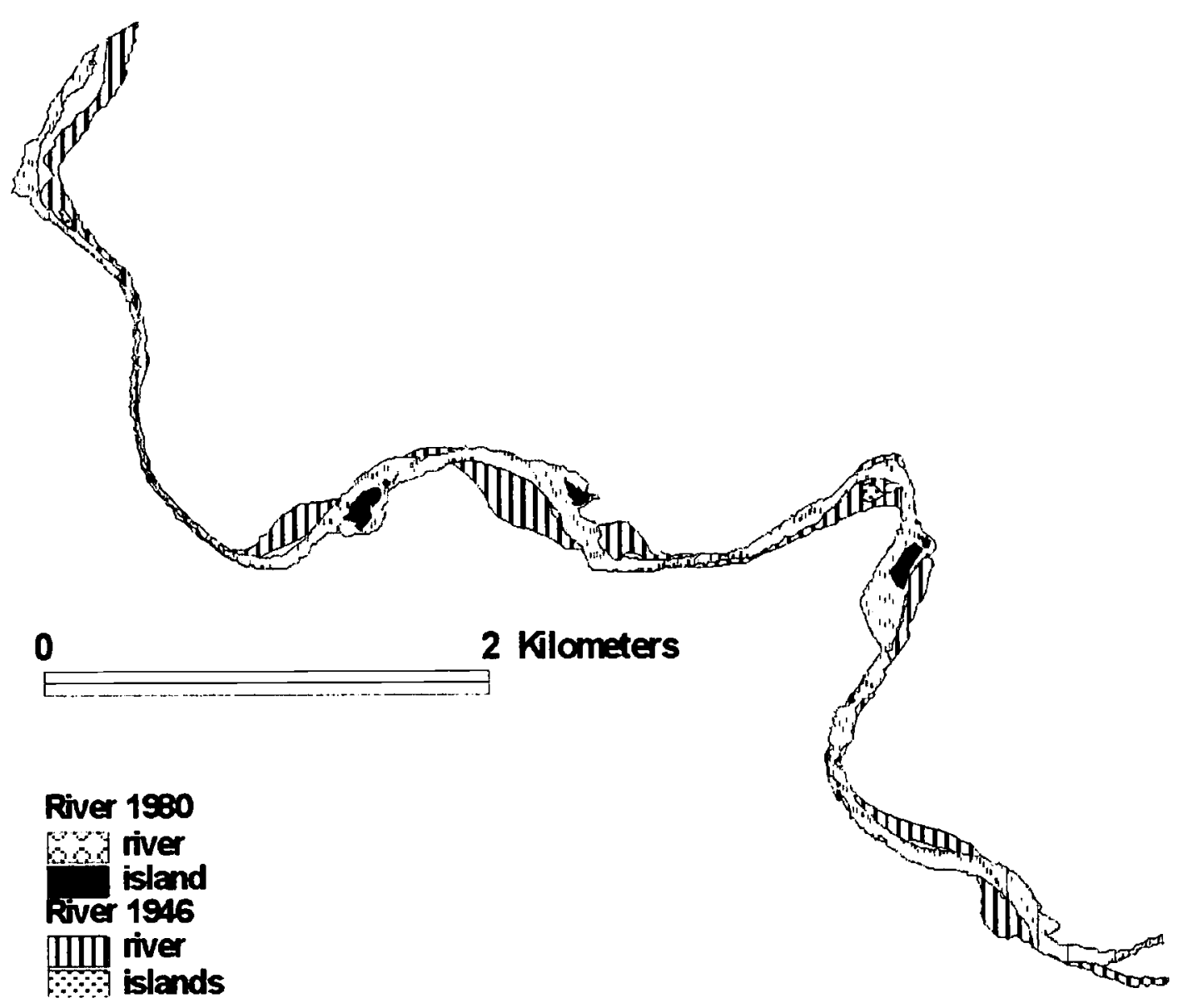

Figure 3. Changes in Channel Position of Rio La Yuca, 1946 to 1980. Notice the movement of the river channel and the islands within it.

indicating that it had already experienced substantial conversion of forest to pasture. In contrast, the La Yuca and Bumbum study areas were almost entirely forested in 1946. Thus the three study areas differed in their history prior to our earliest photographic record, as well as in the extent of land-use change over the nearly 35-year time interval analyzed. The Rio Bumbum is more strongly confined laterally by valley walls than the other two rivers, and differences among watersheds in natural as well as human influences should be acknowledged.

Measurable changes in channel shape were documented between 1946 and 1980 for each river. Howev$\mathrm{er}$, there were differences in the extent and kind of change that was observed. Sinuosity did not change in either Las Marias or the Bumbum, and could not be measured in the La Yuca. Both Las Marias and the Bumbum increased in width, and both Las Marias and La Yuca showed evidence of channel shifts. These results are consistent with other studies that have found land-use change to affect river channels. Comparing 1944 to 1976 aerial photography in rivers of northern Argentina that experienced landscape development, Sayago and Guido (1991) reported an increase in width, meander wavelength, and channel slope, and a decrease in depth and sinuosity producing a change from a meandering to a braided channel. Using aerial photographs (1938 to 1989 ) in a $12-\mathrm{km}$ segment of an Ozarks river that had experienced historic timber harvest and open-range grazing, both of which declined after 1950, Jacobson and Pugh (1997) concluded that regrowth of woody riparian vegetation was the primary cause of increased channel stability over the time period of observation.

Results from the Bumbum study area, where average channel width increased by 25 percent from 1946 to 1980 , strongly support expectations that a change in near-stream land use can alter a stream's morphology. Although the lower catchment of the Bumbum experienced a substantial reduction in forested area 
over this time interval, a thin strip of riparian forest less than $30 \mathrm{~m}$ wide was detectable along much of the stream length in the 1980 photograph and 1999 field visits. Thus, widening of this river channel occurred despite its narrow, confining valley and minimal upstream development.

The increase in channel width was most pronounced for Rio Las Marias, possibly because its wide, flat valley offered little constraint to widening. In addition, this watershed had already experienced substantial deforestation by 1946; possibly changes in channel shape observed between 1946 and 1980 were channel adjustments to prior deforestation. Although Rio La Yuca did not experience an increase in channel width, channel change between 1946 and 1980 was notable. Several islands appeared in the study segment, which may indicate lateral channel movement. Clays were evident in the banks of Rio La Yuca throughout the study region, and possibly the cohesiveness of streambanks led to slumping of banks in places, rather than a general widening.

Channel adjustment in response to changing land use may take different forms for a number of reasons. Local valley physiography significantly influences where channel migration is likely to occur within a stream segment, distinguishing disturbance reaches from stable reaches based on extent of later channel shift. Stable reaches tend to be associated with straight valley walls (Miller and Jacobson, 1995), woody riparian vegetation (Graf, 1978; Jacobson and Pugh, 1997), particle size characteristics of streambank and bed (Schumm, 1960), and other constraining factors. For our study watersheds it is unknown whether hydrologic and sediment budgets have been sufficiently altered to bring about channel shifts, or whether changes in riparian land-use might play a larger role. In addition, time lags in adjustment should be considered. Nonetheless, this study has shown changes in river channels in three tropical watersheds experiencing substantial land-use change over the period 1946 to 1980 , and supports the findings of others (Jacobsen and Pugh, 1997; Sayago and Guido, 1991) that land-use change can influence stream channel form.

\section{ACKNOWLEDGEMENTS}

We thank the University of Michigan Map Library for acquisition of imagery and the National Geographic Society for funds to acquire aerial photographs. Field travel in 1999 was supported by the H.R. Rackham School of Graduate Studies, the International Institute, Undergraduate Research Opportunities Program, and the Center for the Education of Women at the University of Michigan, Ann Arbor. The manuscript benefited from the comments of several reviewers.

\section{LITERATURE CITED}

Allan, J. D., D. L. Erickson, and J. Fay, 1997 The Influence of Catchment Land Use on Stream Integrity Across Multiple Spatial Scales. Freshwater Biology 37:149-161.

Allan, J. D., A. J. Brenner, J. Erazo, L. Fernandez, A. S. Flecker, D. L. Karwan, S. Segnini, and D. C. Taphorn, 2001. Land Use in Watersheds of the Venezuelan Andes: A Comparative Analysis. Conservation Biology (in press).

Anderson, J. R., E. E. Hardy, J. T. Roach, and R. E. Witmer, 1976. A Land Use and Land Cover Classification System for Use With Remote Sensor Data. U.S. Geological Survey Professional Paper 964

Beschta, R. L., 1983. Long-Term Changes in Channel Widths of the Kowai River, Torlesse Range, New Zealand. Journal of Hydrology 22(2):112-122.

Bruijnzeel, L. A. and C. N. Bremmer, 1989. Highland-Lowland Interactions in the Ganges Brahmaputra River Basin: A Review of Published Literature. International Center for Integrated Mountain Development, Katmandu, Nepal, 136 pp.

Castillo, M. M., J. D. Allan, and S. Brunzell, 2000. Nutrient Concentration and Discharge in a MidWestern Agricultural Catchment. Journal of Environmental Quality 29(4):1142-1151.

Cihlar, J., R. Latifovic, J. Chen, J. Beaubien. Z. Li, and S. Magnussen, 2000. Selecting Representative High Resolution Sample Images for Land Cover Studies. Part 2: Application to Estimating Land Cover Composition. Remote Sensing of Environment $72(2): 127-138$.

Franklin, W. R., 2000. Applications of Analytical Cartography. Cartography and Geographic Information Science 27(3):225-237.

Gentry, A. H. and J. Lopez-Parodi, 1980. Deforestation and Increased Flooding of the Upper Amazon. Science 210:1354-56.

Gilvear, D. J., T. M. Waters, and A. M. Milner, 1995. Image Analysis of Aerial Photography to Quantify Changes in Channel Morphology and Instream Habitat Following Placer Mining in Interior Alaska. Freshwater Biology 34:389-398.

Gordon, N. D., T. A. McMahon, and B. L. Findlayson, 1992. Stream Hydrology: An Introduction for Ecologists. John Wiley and Sons, New York, New York.

Graf, W. L., 1978. Fluvial Adjustments to the Spread of Tamarisk in the Colorado Plateau Region. Geological Society of America Bulletin 89:1481-1501.

Hallberg, G. R., J. M. Harbaugh, and P. M. Witinok, 1979. Changes in Channel Area of the Missouri River in Iowa, 1879-1976. Special Report Series 1, Iowa Geological Survey, Iowa City, Iowa, 32 pp.

Jacobsen, R. B. and A. L. Pugh, 1997. Riparian. Vegetation Controls on the Spatial Pattern of Stream-Channel Instability, Little Piney Creek, Missouri. U.S. Geological Survey Water-Supply Paper 2494.

Jureck, K. E., 2000. Channel Stability Downstream From a Dam Assessed Using Aerial Photographs and Stream-Gage Information. Journal of American Water Resources Association 36(3):633-645.

Kondolf, G. M. and R. R. Curry, 1986. Channel Erosion Along the Carmel River, Monterey County, California. Earth Surface Processes and Landforms 11:307-319.

Miller, A. J. and R. B. Jacobson, 1995. Channel. Planform in Confining Valleys. Proceedings, The International Association of Geomorphologists, Southeast Asia Conference, Singapore, Malaysia, pg. 57.

Odgaard, A. J., 1984. Bank Erosion Contribution to Stream Sediment Load. Iowa Institute of Hydraulic Research Report Number 280 .

Richards, C., L. B. Johnson, and G. E. Host, 1996. Landscape-Scale Influences on Stream Habitats and Biota. Canadian Journal of Fisheries and Aquatic Science 53 (Supplement 1):295-311. 
Roth, N. E., J. D. Allan, and D. L. Erickson, 1996. Landscape Influences on Stream Biotic Integrity Assessed at Multiple Spatial Scales. Landscape Ecology 11(3):141-156.

Sayago, Jose Manuel and Elvira Yolanda Guido, 1991. Monitoring Watershed Degradation Through Changes in Fluvial Morphology by Aerial Photographs and Satellite Imagery Interpretation. In: Proceedings, International Symposium on Remote Sensing of Environment, Environmental Research Institute of Michigan, Rio de Janeiro, Brazil, pp. 671-681.

Schumm, S. A., 1960. The Shape of Alluvial Channels in Relation to Sediment Type. U.S. Geological Survey Professional Paper 352B, $30 \mathrm{pp}$.

Schumm, S. A., 1963. Sinuosity of Alluvial Rivers on the Great Plains. Geological Society of America Bulletin 74:1089-1100.

Schumm, S. A., 1977. The Fluvial System. John Wiley and Sons, $333 \mathrm{pp}$.

Schumm, S. A. and R. W. Lichty, 1963. Channel Widening and Flood-Plain Construction Along Cimarron River in Southwestern Kansas. U.S. Geological Survey Professional Paper 352-D, $88 \mathrm{pp}$. 